\title{
Analysis of the Mammal Fauna of the Lublin Coal Basin Based on Owl Pellets
}

\author{
Jerzy KUBIK, Henryk LENIEC \& Wiesław SITKOWSKI
}

Kubik J., Leniec H. \& Sitkowski W., 1983; Analysis of the mammal fauna of the Lublin Coal Basin based on owl pellets. Acta theriol., 29, 13: 167-173 [2 Tables \& 1 Fig.]

An analysis was made, on the basis of owl pellets collected in May and July 1979 in 19 localities, of the Micromammalia fauna in the southern and northern, parts of the Lublin Coal Basin. The pellets originated chiefly from Tyto alba guttata (C. L. Brehm). The greatest percentage $(65.3 \%)$ was formed by rodents, lesser by insectivores $(34.4 \%)$ and only a small percentage $(0.3 \%)$ by bats, in material composed of over 8,000 mammals belonging to 27 species. Referring to studies previously carried out in the central part of this region, attention was drawn to differences in the species composition and percentage of mammals occurring in different parts of the Coal Basin.

[Inst. Biol., M. Curie-Skłodowska, Univ. Akademicka 19, 20-033 Lublin, Poland].

\section{INTRODUCTION}

The purpose of the studies was to determine the species composition and percentages formed by mammals occurring in the Lublin Coal Basin region. They form a continuation of studies initiated by Kubik, Kiwilszo \& Zielinski (1980), who examined the central, and part of the northern areas, of the Basin. The region will first of all be developed, and secondly examined. The species composition of mammals and their proportions in percentages have been considered on the basis of analysis of owl pellets. The study area has not as yet been researched from the aspect of its fauna, although there are papers on the small mammal fauna of neighbouring areas (Skuratowicz, 1948; Nikodem, 1972).

\section{MATERIAL AND METHODS}

Owl pellets were collected in the southern, and part of the northern, area of the Lublin Coal Basin and in areas immediately adjacent to them, in May and July 1979 in 19 localities (Table 1, Fig. 1). The pellets were mainly from the barn owl Tyto alba guttata (C. L. Brehm), and in very small numbers from the tawny owl Strix aluco L. There was no particular difficulty in determining from which species of owl the material originated, on account of the presence of feathers, nests or from observations of the birds. Barn owl pellets were found in the lofts of different buildings (belfries, barns, lofts of churches), and tawny owl pellets under trees in parks.

The pellets were examined wet in accordance with generally accepted principles, removing skulls, mandibles, single teeth and pelvic bones of mammals. 


\section{DESCRIPTION OF THE STUDY AREA}

The Lublin Coal Basin forms an extensive depression about $90 \mathrm{~km}$ long and about $20 \mathrm{~km}$ wide, the region being divided into three parts: northern, central and southern. During the first stage the central and northern parts are to undergo economic development. The central part includes three geographical units: the southern extremes of the Eęczna-Włodawa lake district, the Dorohusk depression and Gielczew uplands. The northern part belongs to the geobotanical region of

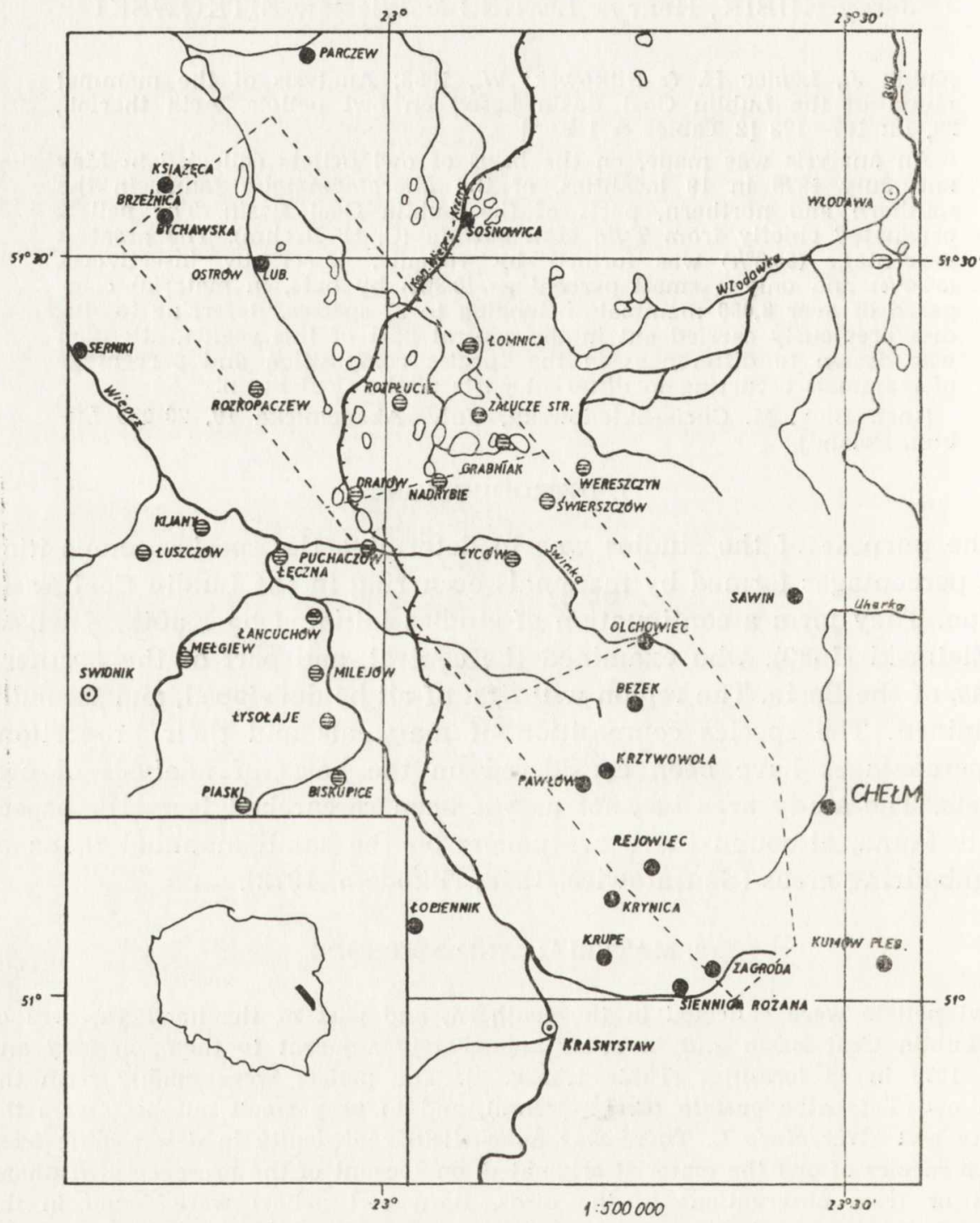

Fig. 1. Map of the study area.

Dark spots - sites on which the owl pellets used for this study were collected, shaded spots - places in which the pellets examined by Kubik et al. (1980) were collected, dotted line indicates the boundaries of the three regions of the Lublin Coal Basin. 
the Eęczna-Włodawa lake district included in the composition of the Polesie region. Both these parts (excluding the Gielczew uplands) are characterized by wet land with a well-developed system of rivers and lakes (Fijalkowski, 1972). The southern area of the Lublin Coal Basin is included in the composition of the Lublin Uplands and comprises in principle ore geographical unit - the Chelm hills, particularly its central and southern parts (Fig. 1). The Chelm hills form a region greatly affected hy erosion and denudation, due to the presence of chalk, which is easily washed away (Fijalkowski, 1972). The whole area is covered with distinct chalk ridges, with frequent karstic depressions periodically retaining a large amount of water. The majority of the soils are fertile chalk soils. Potentilla albae-Quercetum, Pino-Quercetum with Quercus rubra and oak-hornbeam stands of the Tilio-Carpinetum association grow there. On higher land there are patches of steppe vegetation. Patches of xerothermic associations have also persisted in large numbers. A description of the geobotanical conditions of the study areas is to be found in publications by Fijałkowski (1972) and Izdebski \& GrądzieI (1982).

Material was collected chiefly in villages with more or less compact building. The only towns chosen were Chelm, Parczew and Ostrów Lubelski (Fig. 1). The village areas are under fairly intensive cultivation. There is also a number of solitary buildings at considerable distances from the villages. These factors undoubtedly affect the picture of the mammal fauna of these areas.

\section{RESULTS AND DISCUSSION}

A total of 8,142 mammals belonging to three orders - Insectivora, Chiroptera and Rodentia -- were found in the material analyzed. Rodentia is most numerously represented (5,263 individuals from 14 species), which form $65 \%$ of the whole collection. There were smaller numbers of insectivores, (2,758 individuals from 5 species) forming $34.4 \%$. The proportion of Chiroptera $(0.3 \%)$ is low, although as many as 8 species of these mammals were found. In all the presence of representatives of 27 species of Micromammalia were found to be present (Table 1).

In the southern part of the Lublin Coal Basin (Table 1) Sorex araneus, Mus musculus and Microtus arvalis jointly formed $83 \%$ of the collection. The species most numerously represented is Mus musculus $(34.6 \%)$, slightly less numerous $S$. araneus $(22.8 \%)$ and $M$. arvalis $(26.1 \%)$. Theconsiderable proportion of house mice is undoubtedly due to the fairly dense human dvellings in the study area and the synanthropic character of these rodents. The high percentage of $S$. aruneus may be explained by the existence of some relatively humid areas. It was only as Pawlowo, Krynica and Krupe that is, in decidedly dry areas in which cultivated fields predominated, that a small number of these mammals was found. It is difficult to define the typical biotope of this species. A large number of authors - Dehnel (194.9), Borowski \& Dehnel (1953), Kubik (1951) and others have put forward different opinions, but it would seem that the shrew is a eurytopic mammal with a slight tendency to prefer humid habitats (Aulak, 1970). Microtus arvalis occurs on the study stations and in large percentages. 
A relatively large percentage of Crocidura leucodon $(5.4 \%)$ was found in the material, and it was shown to occur chiefly in towns and larger settlements at a distance from stretches of wooded land (in Chelm, Rejowiec, Eopiennik and others). The musk shrew is a decidedly synanthropic species and occurs in a compact range from the east of the Vistula in the central and southern region of Poland (Pucek, 1981).

Single bats were shown to have occurred only on four stations. They were most numerously represented at Siennica Różana in which, out of a total number of 13 bats from these few stations, 9 individuals originated from the above locality. Eptesicus serotinus occurred most numerously, but at Łopiennik, Kumów Plebański and Bezek Vespertilio murinus, Eptesicus serotinus and Plecotus austriacus were found to occur. Pipistrelus nathusi Kayserling et Blasius, rarely recorded in Poland, but found in earlier studies in the Lublin Coal Basin, was not found in the present material.

Of the Muridae family, apart from Mus musculus which has already been mentioned as occurring everywhere and in large numbers, such species as Micromys minutus proved to be relatively less numerous, being found chiefly at Siennica Różana and Kumów Plebański, and also Apodemus sylvaticus $(1.7 \%)$ and Apodemus agrarius $(0.6 \%)$. A. sylvaticus occurred most numerously at Chełm and Krynica, and occurred in fewer numbers in localities distinguished by a high degree of humidity. The field mouse ( $A$. agrarius) was most numerously represented at Kumów Plebański and Krynica. Single individuals of these rodents were found in 6 other localities (Table 1). As can be seen from the above data, A. sylvaticus is relatively numerous in the study area, three times more numerous than in the central part of the Lublin Coal Basin (Kubik et al., 1980). Diversity of biotopes and the high degree of humidity of the central part of the Lublin Coal Basin undoubtedly affect the numbers of this and other Muridae.

Of the family Arvicolidae over $2 \%$ was formed in the collection by Pitymys subterraneus, which occurred most numerously at Kumów Plebański, Siennica Różana, Łopiennik and Krynica. Avoiding wet areas (Wasilewski, 1960) Pitymys subterraneus leads an underground way of life and inhabits wooded land, fields and meadows.

Such species as Clethrionomys glarealus, Arvicola terrestris and Microtus agrestis were found very seldom and in small numbers in the material examined. On the other hand Microtus oeconomus $(1.3 \%)$ is relatively numerously represented, but even so in smaller numbers than in the central and northern part of the Lublin Coal Basin (Kubik et al., 1980). This species was shown to occur chiefly at Kumów Plebański, Chełm and Siennica Różana.

Several individuals of Sicista betulina were found in the owl pellets, chiefly at Siennica Różana and Krynica. 
In supplementing analysis of owl pellet material by a further six localities in the northern part of the Lublin Coal Basin (Fig. 1) the marked coincidence with results hitherto obtained in this area must be emphasised (Kubik et al., 1980). In the study area (Table 1) there was also a considerable numerical preponderance of rodents $(62.5 \%)$ in comparison with insectivores $(37.2 \%)$ and the very slight proportion of Chiroptera $(0.2 \%)$, none of the species Pipistrellus being found.

Out of the total number of 3,271 specimens from pellets originating from Tyto alba guttata, among Insectivora a considerable percentage was formed by shrews $(30.9 \%)$, other species of this order being scarce. A small percentage of Talpa europaea was found in owl pellets obtained mainly from the town of Parczew (Table 1).

Among Rodentia, out of the 14 species found, the far highest percentage was that of Microtus arvalis $(31.8 \%)$ and Mus musculus $(23.4 \%)$. These species occurred in all of the 6 localities examined. A smaller proportion of individuals in the material was formed by Pitymys subterraneus $(3.0 \%)$ and Microtus oeconomus $(2.0 \%)$. The first of these is represented chiefly in two localities - Brzeźnica Książęca and Brzeźnica Bychawska, the second in usually small numbers at all the localities apart from Sosnowica and Ostrów Lubelski.

Muscardinus avellanarius was not found in previous studies in this area (Kubik et al., 1980), but in our material occurred singly in three localities - Brzeźnica Książęca and Brzeźnica Bychawska, and also at Sosnowica. It was then shown, however, that the numbers of Microtus minutus and Apodemus agrarius were high, although they only form a small percentage in our material (Table 1). The differences referred to in the two series of owl pellet material analyzed from the northern part of the Lublin Coal Basin are probably due to the far smaller than hitherto number of collections in the present case.

\section{CONCLUSIONS}

The results of examination of owl pellets, presented above, together with an earlier paper (Kubik et al., 1980) jointly give a general idea of the Micromammalia fauna of the whole of the Lublin Coal Basin region. All the material taken as a whole covers an area slightly more extensive than the coal basin itself (Fig. 1), which should not be of any great significance in an analysis of mammal fauna.

Analysis of owl pellets gives an up-to-date picture of the mammal fauna in this study area and also permits of discovering the occurrence of species of rarely occurring bats, such as Vespertilio murinus or Eptesicus nilssoni, or rodents such as, e.g. M. avellanarius and S. betulina.

The whole material was divided into three groups corresponding to the three parts of the Lublin Coal Basin, distinguished more for technical than physiographic reasons and compared in Table 2. It can be seen 
that biotope conditions are more diversified in the central and northern parts, and that there is a higher proportion of insectivores, particularly of $S$. araneus, than in the southern part. In the northern part, on the other hand, rodents decidedly predominate over insectivores. Among the former $M$. musculus and $M$. arvalis predominate (Table 2).

\section{Tabela 2}

Percentages formed by three orders of mammals and three dominant species in three regions of the Lublin Coal Basin. The results of earlier studies (Kubik et al., 1980) have been taken into account.

\begin{tabular}{lccc}
\hline Region & $\begin{array}{c}\text { Central } \\
\mathrm{n}=5,746\end{array}$ & $\begin{array}{c}\text { Northern } \\
\mathrm{n}=9,229\end{array}$ & $\begin{array}{r}\text { Southern } \\
\mathrm{n}=4,871\end{array}$ \\
\hline Order & & & \\
Insectivora & 47.1 & 41.2 & 31.5 \\
Chiroptera & 0.5 & 0.2 & 0.3 \\
Rodentia & 52.4 & 58.6 & 68.2 \\
\hline Species & & & \\
S. araneus & 36.0 & 32.9 & 22.8 \\
M. musculus & 26.9 & 26.5 & 34.7 \\
M. arvalis & 11.5 & 20.6 & 26.1 \\
\hline
\end{tabular}

The industrialization of this region which is taking place will undoubtedly alter ecological relations and the composition of Micromammalia fauna. Assuming that these studies will be repeated in the future it will be possible, also in the future, to define the character and degree of the changes taking place. A knowledge of such changes may be of considerable importance to protection of fauna when preparing projects in the future for such large-scale industrial undertakings as the Lublin Coal Basin.

\section{REFERENCES}

1. Aulak W., 1970: Small mammal communities of the Bialowieża National Park. Acta theriol., 15: 465-513.

2. Borowski S. \& Dehnel A., 1953: Materiały do biologii Soricidae. Annls Univ. Mariae Curie-Skłodowska, sect. C, 7: 305-448.

3. Dehnel A., 1949: Badania nad rodzajem Sorex L. Annls Univ. Mariae Curie-Skłodowska, sect. C, 4: 17-102.

4. Dehnel A., 1950: Badania nad rodzajem Neomys Kaup. Annls Univ. Mariae Curie-Skłodowska, sect. C, 5: $1-64$.

5. Fijałkowski D., 1972: Stosunki geobotaniczne Lubelszczyzny. Ossolineum: 1-150. Wrocław.

6. Izdebski K. \& Grądziel T., 1981: Pojezierze Łęczycko-Włodawskie. Wiedza Powsz.: 1-202. Warszawa.

7. Kubik J., 1951: Analiza puławskiej populacji Sorex araneus araneus L. i Sorex minutus minutus L. Annls Univ. Mariae Curie-Skłodowska, sect. C, 5: 335-372.

8. Kubik J., Kiwilszo W. \& Zieliński W., 1980: Fauna ssaków centralnego i północnego okręgu Lubelskiego Zagłębia Węglowego na podstawie analizy zrzutek sów. Annls Mariae Curie-Skłodowska, sect. C, 35: 221-228. 
9. Nikodem Z., 1972: Analiza zrzutek sowich $\mathrm{z}$ terenu widel Wisły i Wieprza. Przegl. zool., 15: 15-20.

10. Pucek Z. (ed), 1981: Keys to Vertebrates of Poland, Mammals. Państw. Wyd. Nauk.: 1-367. Warszawa.

11. Skuratowicz W., 1948: Badania nad fauną ssaków Zamojszczyzny. Fragm. Faun., 5: $233-292$.

12. Wasilewski W., 1960: Angaben zur Biologie und Morphologie der Kurzohrmaus, Pitymys subterraneus (de Sélys-Longchamps, 1836). Acta theriol., 4: 185-247.

Accepted, April 6, 1984.

Jerzy KUBIK, Henryk LENIEC i Wiesław SITKOWSKI

\section{ANALIZA FAUNY SSAKOW LUBELSKIEGO ZAGEĘBIA WĘGLOWEGO NA PODSTAWIE ZRZUTEK SÓW}

\section{Streszczenie}

$\mathrm{Na}$ podstawie zrzutek sów z terenu Lubelskiego Zagłębia Węglowego przeprowadzono analizę składu i udziału procentowego fauny Micromammalia. Wypluwki pochodziły głównie od Tyto alba guttata C. L. Brehm i zostały zebrane w maju i lipcu 1979 roku w 19 miejscowościach regionu południowego oraz częściowo północnego Lubelskiego Zagłębia Węglowego. W materiale ponad 8 tysięcy ssaków, stwierdzono największy procent gryzoni $(65,3 \%)$, mniejszy owadożernych $(34,4 \%)$ i niewielki procent nietoperzy (Tabela 1). Wykazano obecność 27 gatunków ssaków, w tym niektóre dotychczas rzadko występujące na Lubelszczyźnie: Verspertilio murinus i Eptesicus nilssoni. Ogólnie stwierdzono, znaczną przewagę procentową gryzoni w regionie południowym w porównaniu do centralnego i pólnocnego obszaru Lubelskiego Zagłębia Węglowego i to głównie takich ssaków jak - Mus musculus i Microtus arvalis (Tabela 2).

Autorzy sugerują konieczność w przyszlości powtórzenia badań faunistycznych w związku z uprzemysłowieniem Lubelskiego Zagłębia Węglowego i zmiany warunkbw ekologicznych tego terenu. 